\title{
Evaluation of Changes in Accounting Standards from SAK ETAP to SAK: Case Study of a Power- Plant Company
}

\author{
Aditia Hariadi Tamar \\ Department of Accounting \\ Faculty of Economics and Business, Universitas Indonesia \\ Depok, Indonesia \\ aditia.tamar@gmail.com
}

\author{
Kurnia Iwansyah Rais \\ Department of Accounting \\ Faculty of Economics and Business, Universitas Indonesia \\ Depok, Indonesia \\ kurnia.i.rais@hotmail.com
}

\begin{abstract}
This study addresses the implementation of changes in accounting standards from those without public accountability (SAK ETAP) to normal financial accounting standards (SAK). Indonesia has three pillars of accounting standards that can be voluntarily chosen. PT A, the subject of our case study, used SAK ETAP until they sought to get fresh funds through an initial public offering. Under financial services authority rules, PT A's financial statements required to go public had to be prepared using SAK. This study seeks to discover the differences and impacts arising from moving from SAK ETAP to SAK. The various hypotheses tested in the literature concerning the changes in accounting policies show that changes have been made for income smoothing. The biggest impact seems to entail the restatement of financial statements, consolidation principles, deferred taxes, postemployment benefits, financial instruments, and statements of cash flow. The figures of financial position and profit and loss are adjusted, resulting in increased profits and improved financial ratios. This is contradictory to several hypotheses tested in previous studies stating that changes in accounting policies tended to cause income smoothing.
\end{abstract}

Keywords-changes in accounting standards, retrospective application, consolidated financial statements

\section{INTRODUCTION}

Financial statements are structures that present the financial position and performance of a company. The purpose of financial statements is providing information on financial position, performance, and cash flow, providing useful information that can be accountable both to internal and external parties [1]. When preparing financial statements, a company must comply with applicable accounting standards.

PT A has power plant projects in several locations in Indonesia. It also owns shares in subsidiaries and has significant influence. The company was initially an entity whose public accountability was insignificant. Therefore, they used accounting standards without public accountability (SAK ETAP) when preparing financial statements. The company has plans to expand its business, requiring considerable working capital. Currently, many companies make public offering as a means of obtaining working capital. To realize PT A's plan, there are requirements that must be fulfilled, as regulated by the Financial Services Authority and the Indonesian Stock Exchange. Financial statements are required for a period of 3 years or from the establishment of a company, given there is a profit in the last year. They must get an unqualified opinion on the financial statements for the last 2 years if they have net tangible assets of more than Rp100 billion. With the public offering plan, the company ceases to be an entity whose public accountability is insignificant. Thus, they must adopt the normal financial accounting standard (SAK).

Changes in the implementation of a company's accounting policies constitute significant changes to their financial statements. Thus, studies have been undertaken to determine the differences between SAK ETAP and SAK, how their implementation is implemented, and the financial impacts arising from such changes. The method used in this study includes a literature study for data collection, including PT A's financial statements. From this study, we obtain the differences between implementations of SAK ETAP and SAK and their different impacts.

\section{ANALYTICAL FRAMEWORK}

\section{A. Financial Reporting and Standards}

According to [2], financial statements are useful to investors and creditors for making decisions. Financial statements should contain useful, comparable, and understandable information about economic and business activities. An entity is required to voluntarily choose their applicable financial accounting standards.

Financial accounting standards in Indonesia comprise three pillars of financial accounting standards, including SAK, SAK ETAP, and SAK for micro, small, and medium entities (EMKM) [3]. SAK is an accounting standard that regulates the accounting treatment for transactions conducted by entities with significant public accountability. SAK ETAP is a financial accounting standard for entities without significant public accountability who publishes generalpurpose financial statements. Meanwhile, SAK EMKM is intended to meet the financial reporting needs of small-tomedium businesses.

Statement of Financial Accounting Standards (PSAK) 25 [4], entitled, "Changes in accounting policy, accounting estimates, and errors," is an adoption of International Accounting Standards (IAS) 8, entitled "Accounting policies, changes in accounting estimates and errors." If an entity changes their accounting policy as a preliminary application 
of a PSAK, it must be applied retrospectively by adjusting the beginning balance of each affected equity component for the earliest serving period and other comparative amounts disclosed for each period as if the new accounting policy had been applied previously.

Consolidation is essentially a two-stage process to eliminate any and all balances or transactions between groups and combine the same figures to describe the group as a single entity [5].

\section{B. Financial Analysis}

The role of financial statement analysis is to use financial reports combine with other information to evaluate the current, past, and potential performance and financial position of the entities for making economic decision [6].

\section{METHOD}

The purpose of this study is to evaluate the changes in accounting standards from SAK ETAP to SAK and the impacts of those changes on the financial reporting of PT A as a case study. To achieve the objectives of the study, an analysis is conducted by using literature study and by collecting and reviewing guidelines on SAK and related accounting standards.

\section{RESUlTS AND DisCUSSION}

From the data collection and literature study, we learned the differences affecting the financial statements of PT A as they moved from SAK ETAP to SAK. First, from the presentation of financial statements, there were some changes arising from the use of balance sheets and liabilities to statements of financial position and liabilities. Other comprehensive income components required for SAK included additional financial accounting items that were not previously needed in SAK ETAP, such as deferred tax assets and non-controlling interests arising from consolidation if the company has investments in shares in a subsidiary. Another factor was the cash-flow statement of operating activities suggested in SAK, which required the direct method. Another was related to the recognition and measurement of multiple accounts, including borrowing costs on interest costs and others incurred in connection with the borrowing of funds entities according to PSAK No. 26 (2017) to obtain a qualifying asset to be capitalized as part of the costs of those assets. SAK ETAP recognizes those costs as expenses in the statements of income. SAK also regulates the recognition and measurement of deferred taxes on temporary differences, including those of the carrying amount of assets and liabilities in the financial statements and taxes. Differences are also seen in the recognition and measurement of postemployment benefits. SAK ETAP uses projected unit cost method, which is simpler than SAK and is recommended by independent actuaries. Differences are also be reflected in the financial instrument section. The scope of financial instruments within the SAK was regulated under PSAK 50, entitled, "Financial instruments: presentation," which also regulates presentation. PSAK 55, entitled, "Financial instrument: recognition and remeasurement," describes the recognitions and measurements required. PSAK 60 is entitled, "Financial instrument: disclosure." In SAK, the scope of financial instruments includes financial assets and liabilities classified at fair value through profit or loss, held to maturity, available for sale, loans and receivables. With
SAK ETAP, the scope of financial instruments is simpler, including investments in certain securities traded (marketable securities) available for sale and held to maturity. Significant changes in the company's financial statements having investments in subsidiaries are the existence of consolidation procedures. Consolidation is accomplished via the merger of the financial statement of each subsidiary entity in which the company has significant equity participation and control. Therefore, there are non-controlling interests in the consolidated financial statements using SAK, whereas SAK ETAP is not consolidated with subsidiaries.

From the literature study, changes were deciphered by collecting the original data, which was then reprocessed to obtain a comparison of financial statements when using SAK ETAP compared to SAK, as shown in Table 1. After implementing SAK, some of the company's balances changed. Changes in balances of property, plant, and equipment resulting from the capitalization of borrowing costs consisted of interest expenses arising from bank loans. The capitalization of borrowing costs also affected changes in profit and loss balances, as presented in Table 2. Thus, the company's retained earnings also changed. They also recorded deferred tax assets as a result of the implementation of PSAK 46, "Income tax." Table 1 also shows the financial statements after consolidation. The balance presented in the consolidated financial statements is a combination of the company's balance with its subsidiaries. Therefore, investments in subsidiaries do not appear in the consolidated statements, because they have been eliminated. Furthermore, the balance of trade receivables owned by the subsidiaries and the record of non-controlling interests are the shareholders of the subsidiaries other than the parent entity, appearing only in the consolidated statements.

From the results of PSAK implementation changes in balances occurred, so that the financial performance of the company, as reflected in the financial statements, was also different. This difference can be understood by calculating the financial ratios shown in Table 2 . Table 3 presents the results of financial ratio calculations before and after SAK implementation.

TABLE I. COMPARISON OF STATEMENTS OF FINANCIAL POSITION BETWEEN SAK ETAP AND SAK AND SAK AFTER CONSOLIDATION

\begin{tabular}{|c|c|c|c|}
\hline $\begin{array}{c}\text { Accounts } \\
\text { Description }\end{array}$ & $\begin{array}{c}\text { Implementation } \\
\text { of SAK ETAP }\end{array}$ & $\begin{array}{c}\text { Implementation } \\
\text { of SAK }\end{array}$ & $\begin{array}{c}\text { Implementation } \\
\text { of SAK }\end{array}$ \\
\cline { 2 - 4 } & (PT A) & $\begin{array}{c}\text { (PT A-Single } \\
\text { Entity) }\end{array}$ & (Consolidation) \\
\hline ASSETS & & & $5,434,762,899$ \\
\hline $\begin{array}{c}\text { Cash and Cash } \\
\text { Equivalent }\end{array}$ & $567,313,445$ & $567,313,445$ & $11,849,671,222$ \\
\hline $\begin{array}{c}\text { Trade } \\
\text { Receivable }\end{array}$ & $7,000,000$ & $7,000,000$ & $2,635,107,979$ \\
\hline $\begin{array}{c}\text { Other } \\
\text { Receivables }\end{array}$ & $128,377,127$ & $128,377,127$ & $460,258,378$ \\
\hline $\begin{array}{c}\text { Prepaid } \\
\text { Expenses }\end{array}$ & $7,951,393,056$ & $7,951,393,056$ & $8,028,710,901$ \\
\hline $\begin{array}{c}\text { Prepaid Taxes } \\
\text { Due from } \\
\text { Related Parties } \\
\text {-Non-Trade }\end{array}$ & $4,231,934,610$ & $4,231,934,610$ & $12,970,038,247$ \\
\hline $\begin{array}{c}\text { Total Current } \\
\text { Assets }\end{array}$ & $\mathbf{1 2 , 8 8 6 , 0 1 8 , 2 3 9}$ & $\mathbf{1 2 , 8 8 6 , 0 1 8 , 2 3 9}$ & $\mathbf{4 1 , 3 7 8 , 5 4 9 , 6 2 7}$ \\
\hline
\end{tabular}


TABLE I. CONTINUE

\begin{tabular}{|c|c|c|c|}
\hline $\begin{array}{c}\text { Investment in } \\
\text { Subsidiaries }\end{array}$ & $19,622,038,311$ & $19,651,476,094$ & \\
\hline $\begin{array}{l}\text { Property, } \\
\text { Plant, and } \\
\text { Equipment }\end{array}$ & $74,985,476,109$ & $89,533,939,827$ & $92,823,148,561$ \\
\hline $\begin{array}{l}\text { Deferred } \\
\text { Expenses }\end{array}$ & $30,248,530,464$ & $30,248,530,464$ & $30,248,530,464$ \\
\hline $\begin{array}{c}\text { Deferred Tax } \\
\text { Assets }\end{array}$ & - & $22,607,734$ & $165,179,828$ \\
\hline $\begin{array}{l}\text { Other Non- } \\
\text { Current } \\
\text { Financial } \\
\text { Assets }\end{array}$ & $294,620,695$ & $294,620,695$ & $294,620,695$ \\
\hline $\begin{array}{l}\text { Total Non- } \\
\text { Current } \\
\text { Assets }\end{array}$ & $125,150,665,579$ & 139,751,174,814 & $123,531,479,547$ \\
\hline $\begin{array}{l}\text { TOTAL } \\
\text { ASSETS } \\
\end{array}$ & $138,036,683,819$ & $152,637,193,053$ & $164,910,029,174$ \\
\hline \multicolumn{4}{|l|}{ LIABILITIES } \\
\hline Trade Payables & $15,370,438,272$ & $15,370,438,272$ & $17,485,910,280$ \\
\hline Tax Payables & $6,940,820$ & $6,940,820$ & $206,498,574$ \\
\hline $\begin{array}{l}\text { Short-term } \\
\text { Bank Loan }\end{array}$ & $11,174,705,422$ & $11,174,705,422$ & $11,174,705,422$ \\
\hline $\begin{array}{c}\text { Total Current } \\
\text { Liabilities }\end{array}$ & $26,552,084,514$ & $26,552,084,514$ & $28,867,114,276$ \\
\hline $\begin{array}{l}\text { Due to Related } \\
\text { Parties Non- } \\
\text { Trade }\end{array}$ & $12,347,430,000$ & $12,347,430,000$ & $12,515,626,200$ \\
\hline $\begin{array}{l}\text { Consumer } \\
\text { Financing } \\
\text { Liabilities } \\
\end{array}$ & $74,377,696$ & $74,377,696$ & $1,035,864,108$ \\
\hline Bank Loan & $64,123,054,841$ & $64,123,054,841$ & $64,123,054,841$ \\
\hline $\begin{array}{c}\text { Post- } \\
\text { employment } \\
\text { Benefits } \\
\text { Liabilities } \\
\end{array}$ & $90,430,936$ & $90,430,936$ & $660,719,310$ \\
\hline $\begin{array}{l}\text { Total Non- } \\
\text { Current } \\
\text { Liabilities }\end{array}$ & $76,635,293,473$ & $76,635,293,473$ & $78,335,264,459$ \\
\hline $\begin{array}{c}\text { TOTAL } \\
\text { LIABILITIES }\end{array}$ & $103,187,377,987$ & $103,187,377,987$ & $107,202,378,735$ \\
\hline \multicolumn{4}{|l|}{ EQUITY } \\
\hline Capital Stock & $34,906,383,005$ & $34,906,383,005$ & $34,906,383,005$ \\
\hline $\begin{array}{c}\text { Additional } \\
\text { Paid-in Capital } \\
\end{array}$ & $19,768,616,995$ & $19,768,616,995$ & $19,768,616,995$ \\
\hline $\begin{array}{l}\text { Retained } \\
\text { Earning }\end{array}$ & $(19,825,694,168)$ & $(5,225,184,933)$ & $(3,751,975,003)$ \\
\hline Total Equity & $34,849,305,832$ & $49,449,815,067$ & $50,923,024,997$ \\
\hline $\begin{array}{c}\text { Non- } \\
\text { Controlling } \\
\text { Interests }\end{array}$ & & & $6,784,625,442$ \\
\hline Total Equity & & & $57,707,650,439$ \\
\hline $\begin{array}{c}\text { TOTAL } \\
\text { LIABILITIES } \\
\text { AND } \\
\text { EQUITY } \\
\end{array}$ & $138,036,683,819$ & $152,637,193,053$ & $164,910,029,174$ \\
\hline
\end{tabular}

TABLE II. COMPARISON OF STATEMENTS OF PROFIT OR LOSS BETWEEN SAK ETAP AND SAK AND SAK AFTER CONSOLIDATION

\begin{tabular}{|c|c|c|c|}
\hline $\begin{array}{c}\text { Accounts } \\
\text { Description }\end{array}$ & $\begin{array}{c}\text { Implementation } \\
\text { of SAK ETAP }\end{array}$ & $\begin{array}{c}\text { Implementation } \\
\text { of SAK }\end{array}$ & $\begin{array}{c}\text { Implementation } \\
\text { of SAK }\end{array}$ \\
\cline { 2 - 4 } & PT A & PT A & Consolidation \\
\hline Revenues & $44,947,305,945$ & $44,947,305,945$ & $60,783,883,732$ \\
\hline $\begin{array}{c}\text { Cost of } \\
\text { Revenues }\end{array}$ & $(35,818,369,473)$ & $(35,818,369,473)$ & $(45,277,359,335)$ \\
\hline Gross Profit & $\mathbf{9 , 1 2 8 , 9 3 6 , 4 7 2}$ & $\mathbf{9 , 1 2 8 , 9 3 6 , 4 7 2}$ & $\mathbf{1 5 , 5 0 6 , 5 2 4 , 3 9 7}$ \\
\hline $\begin{array}{c}\text { Selling } \\
\text { Expenses }\end{array}$ & $(601,015,812)$ & $(601,015,812)$ & $(759,341,920)$ \\
\hline $\begin{array}{c}\text { General and } \\
\text { Administration } \\
\text { Expenses }\end{array}$ & $(4,460,634,682)$ & $(4,460,634,682)$ & $(9,653,096,836)$ \\
\hline $\begin{array}{c}\text { Other Income } \\
\text { Other }\end{array}$ & $1,411,659,766$ & $1,411,659,766$ & $657,445,864$ \\
\hline $\begin{array}{c}\text { Expenses } \\
\text { Profit Before }\end{array}$ & $(\mathbf{2 , 4 4 4 , 4 1 0 , 9 8 0 )}$ & $\mathbf{5 , 1 4 4 , 4 1 9 , 2 3 6}$ & $\mathbf{5 , 3 6 6 , 6 3 5 , 0 4 5}$ \\
\hline $\begin{array}{c}\text { Tax } \\
\text { Befenefit }\end{array}$ & $\mathbf{( 2 , 4 4 4 , 4 1 0 , 9 8 0 )}$ & $\mathbf{5 , 1 5 5 , 1 3 8 , 3 5 0}$ & $\mathbf{5 , 4 1 9 , 4 0 8 , 1 3 4}$ \\
\hline $\begin{array}{c}\text { Profit for the } \\
\text { Year }\end{array}$ & $\mathbf{( 3 3 4 , 5 2 6 , 5 0 8 )}$ & $(384,896,460)$ \\
\hline
\end{tabular}

TABLE III. COMPARISON OF FINANCIAL RATIOS

\begin{tabular}{|c|c|c|c|}
\hline Description & SAK ETAP & SAK & $\begin{array}{c}\text { After } \\
\text { Consolidation } \\
\end{array}$ \\
\hline ROA (\%) & -1.77 & 3.38 & 3.29 \\
\hline Net income & $(2,444,410,980)$ & $5,155,138,350$ & $5,419,408,134$ \\
\hline Total asset & $138,036,683,819$ & $152,637,193,053$ & $164,910,029,174$ \\
\hline ROE (\%) & -7.01 & 10.42 & 9.39 \\
\hline Net income & $(2,444,410,980)$ & $5,155,138,350$ & $5,419,408,134$ \\
\hline Total equity & $34,849,305,832$ & $49,449,815,067$ & $57,707,650,439$ \\
\hline $\begin{array}{c}\text { Debt to Asset } \\
(\%)\end{array}$ & 74.75 & 67.60 & 65.01 \\
\hline Debt & $103,187,377,987$ & $103,187,377,987$ & $107,202,378,735$ \\
\hline Total asset & $138,036,683,819$ & $152,637,193,053$ & $164,910,029,174$ \\
\hline $\begin{array}{c}\text { Debt-to- } \\
\text { Equity (\%) }\end{array}$ & 296.10 & 208.67 & 185.77 \\
\hline Debt & $103,187,377,987$ & $103,187,377,987$ & $107,202,378,735$ \\
\hline Total Equity & $34,849,305,832$ & $49,449,815,067$ & $57,707,650,439$ \\
\hline $\begin{array}{l}\text { Gross profit } \\
\text { margin }\end{array}$ & 20.31 & 20.31 & 25.51 \\
\hline Gross profit & $9,128,936,472.0$ & $9,128,936,472.0$ & $15,506,524,396.9$ \\
\hline Revenue & $44,947,305,945.0$ & $44,947,305,945.0$ & $60,783,883,732.3$ \\
\hline $\begin{array}{c}\text { Operating } \\
\text { profit margin }\end{array}$ & -5.44 & 11.45 & 8.83 \\
\hline $\begin{array}{c}\text { Profit Before } \\
\text { Tax }\end{array}$ & $(2,444,410,980.0)$ & $5,144,419,236.0$ & $5,366,635,044.6$ \\
\hline Revenue & $44,947,305,945.0$ & $44,947,305,945.0$ & $60,783,883,732.3$ \\
\hline $\begin{array}{c}\text { Net profit } \\
\text { margin }\end{array}$ & -5.4 & 11.5 & 8.9 \\
\hline $\begin{array}{c}\text { Profit After } \\
\text { Tax } \\
\end{array}$ & $(2,444,410,980.0)$ & $5,155,138,350.0$ & $5,419,408,133.8$ \\
\hline Revenue & $44,947,305,945.0$ & $44,947,305,945.0$ & $60,783,883,732.3$ \\
\hline
\end{tabular}


Return on assets (ROA) is a ratio describing how efficient a company is when using assets to generate profits. The higher the ROA, the better the company generates profit. After SAK implementation, the company's ROA was better than before. Return on equity (ROE) is a ratio measuring the efficiency of generating profit without needing much capital. The higher the ratio, the better the efficiency. PT A's ROE was higher after implementation of SAK. Debt-to-assets is a ratio describing the percentage of total assets financed by liabilities. A higher ratio indicates the company has increased risk. PT A's ratio was lower after implementing the SAK. Debt-to-equity is a ratio describing how much debt the company uses to financing operations. The higher the ratio, the riskier the enterprise. The company's ratio was lower after implementing the SAK.

Profit margin describes how much profit a company earned from sales generated. The greater the margin, the greater the profits earned. The margin ratio generated by the company after implementing IFRS provided a better picture of company performance compared to before. The company's financial ratio was better after implementing SAK, especially in terms of the ratio related to profit and loss. This is caused by the capitalization of borrowing costs. The consolidated financial ratios also give good descriptions of the company's performance.

\section{CONCLUSION}

This study evaluated the changes in accounting standards from SAK ETAP to SAK for PT A, our case study. The evaluation demonstrated the fundamental differences in accounting treatments from SAK ETAP to SAK. Presentation of comprehensive income and terms are slightly different for the financial statements, requiring retrospective restatement, consolidation, recognition of deferred taxes, classification of financial assets and liabilities, disclosure of financial risk management, and cash-flow statements using the direct method. The figures of financial position and profit and loss were adjusted because of changes in accounting standards, resulting in increased profits and a tendency of improved financial ratios. This contradicts several hypotheses tested in other studies, which stated that companies that implemented changes in accounting policies tended to encounter income smoothing [7]. Intention management is related to changing accounting standards, depending on circumstances, either because of mandatory requirements or earning management is possible.

In the future, this research should be expanded to compare other standard financial accounting pillars in Indonesia, such as SAK EMKM with SAK ETAP or SAK EMKM with SAK. Further research is also needed to compare and analyze costs occurring and the economy impact related to the adoption of changes in accounting standards.

\section{ACKNOWLEDGMENT}

Participating in the University of Indonesia MAKSI program has been a period of intense learning for me, not only on an academic level, but also on a personal level. I would like to acknowledge the people who have supported and helped me throughout this period.

I would first like to thank my mentor and as the second writer in this paper, Kurnia Irwansyah Rais, M.Ak. I am grateful for his guidance, mentorship and patience while this period for doing research. I would also like to thank to Dr. Gede Harja Wasistha as chairman of University of Indonesia MAKSI PPAK program. Finally, I would like to thank my parents who have provided support and affection so far.

\section{REFERENCES}

[1] Dewan Standar Akuntansi Keuangan Ikatan Akuntan Indonesia. (2017). Standar Akuntansi Keuangan Efektif per 1 Januari 2017. Ikatan Akuntan Indonesia.

[2] White, Sondhi., Dov Fried. (2003). The Analysis and Use of Financial Statements, Third Edition. USA: John Wiley \& Sons Inc.

[3] Kartikahadi, Hans., Sinaga, Uli Rosita., Syamsul, Merliyana., Siregar, Sylvia Veronica., Wahyuni, Ersa Tri (2016) Akuntansi Keuangan Berdasarkan SAK Berbasis IFRS. $2^{\text {nd }}$ edition. Ikatan Akuntan Indonesia.

[4] Dewan Standar Akuntansi Keuangan Ikatan Akuntan Indonesia. (2011). Standar Akuntansi Keuangan Entitas Tanpa Akuntabilitas Publik. Ikatan Akuntan Indonesia.

[5] Dunn, J. (2010). Financial Reporting and Analysis. John Wiley \& Sons Inc.

[6] Robinson, T. R., Henry, E., Pirie, W. L., Broihahn, M. A. (2015). International Financial Statement Analysis, Third Edition, CFA Institute. John Wiley \& Sons Inc.

[7] Enomoto, M. (2015). Reexamination of Changes in Accounting Policy: Evidence from Japan. Research Institute for Economics and Business Administration Kobe University. 